\title{
Differences in Surface Hardness of Bovine Enamel after Exposure of Theobromine, Alkaloid Cocoa Pod Extract and Acidulated Phosphate Fluoride
}

\author{
Tamara Yuanita, Nanik Zubaidah and Jesica Ceren \\ Department of Conservative Dentistry, \\ Faculty of Dental Medicine, Universitas Airlangga, \\ Surabaya, Indonesia
}

\begin{abstract}
Background: Acid diet could process demineralization on enamel surface. Process remineralization needed to prevent caries occurrence. The excessive fluorine usage could induce adverse side effects, therefore the development of natural resources such as theobromine and alkaloid cocoa extract as a remineralization is needed. Purpose: To discover the differences of bovine teeth enamel surface hardness after exposure to theobromine, alkaloid cocoa pod extract and acidulated phosphate fluoride. Methods: Twenty-eight tooth crowns of bovine insisivus cut into the shape of the square then planted on the resin mold round shape and divided into four groups. The control group without treatment, the group I was exposed APF, the group II was exposed $1000 \mathrm{mg} / \mathrm{L}$ alkaloid cocoa pod extract, group III was exposed $200 \mathrm{mg} / \mathrm{L}$ Theobromine $200 \mathrm{mg} /$ L. Surface hardness measured using Wolpert Wilson Vickers Microhardness Tool. Results: The group of theobromine produces the highest enamel surface hardness. The enamel surface hardness in alkaloid group of cocoa pod extract was higher compared to the APF group and the control group. Conclusion: The hardness surface of bovine tooth enamel after exposure to theobromine and alkaloid cocoa pod extract is harder than exposure to acidulated phosphate fluoride.
\end{abstract}

Keywords: Theobromine; Alkaloid; Cocoa Pod Extract; Acidulated Phosphate Fluoride; Enamel Surface Hardness

Correspondence: Tamara Yuanita, Department of Conservative Dentistry, Faculty of Dental Medicine, Airlangga University. Jl. Mayjen Prof. Dr. Moestopo 47, Surabaya, Indonesia, 60132. Email: tamara-y@fkg.unair.ac.id,

\section{INTRODUCTION}

Caries is a multifactorial disease that occur due to interactions between sugars in food, biofilms and tissues in oral cavity. Caries is an accumulation of demineralization and remineralization cycles that occur on the enamel surface $^{1}$. Enamel is the outermost and hardest part of tooth that contains mostly hydroxyapatite crystals. The hydroxyapatite crystal amount affects the enamel thickness ${ }^{2}$. These crystals are permeable to ions and molecules that come in direct contact with enamel surface. When the acid encounters the enamel, demineralization occurs in the results of a decrease in the enamel surface hardness. This is the caries initial stage ${ }^{3}$. The enamel ability to resist acid is affected by the enamel chemical composition which varies in each individual and other factor that affect tooth structure $^{4}$.

Robinson, Brookes \& Kirkham ${ }^{5}$ stated that after enamel fully formed, enamel become the only dental tissue that does not have ability to regenerate. This supports the importance of preventing enamel demineralization. one of ways to increase the surface hardness and repair the damage from enamel demineralization is by remineralization through the assistance of remineralizing agents ${ }^{6,7}$.

The most often used remineralizing agent is fluorine as active ingredients to prevent caries development by forming fluorapatite and calcium fluoride which inhibit the work of bacterial enzymes through its antimicrobial properties ${ }^{8,9}$. The fluorine can be given topically and systemically. APF (acidulated phosphate fluoride) with 1.23\% concentration is commonly used due to stability and availability. Phosphoric acid in APF could etch the tooth enamel, then fluoride ion replaces the mineral hydroxyapatite to form a more stable, and more resistance to acids ${ }^{10}$.

A high intake of fluoride is leading to its adverse effects such as dental fluorosis, skeletal fluorosis, bone fractures and toxicity ${ }^{11}$. It is needed a research to find natural substances that work in bone remineralization while preventing bacterial growth and have minimal side effects.

Cacao pod (Theobroma cacao L.) is a natural resource that can be used as a remineralization agent. Cocoa contain secondary metabolite in the form of purine alkaloid which derive from xanthine such as theobromine, caffeine, and theophylline ${ }^{9}$. Amaechi et al. ${ }^{12}$ stated that theobromine in 
cocoa fruit has better effect in remineralization process and enamel hardening. Theobromine makes calcium and phosphate in saliva to combine into crystals that are sized four times larger than hydroxyapatite crystals ${ }^{13}$. Qasthari, Irawan \& $\mathrm{Herda}^{14}$ research stated that theobromine gel with concentration of $200 \mathrm{mg} / \mathrm{L}$ for 48 minutes and 96 minutes can increase enamel hardness. Duraisamy et $a l .{ }^{1}$ also supported the statement, in his research stated that 200 $\mathrm{mg} / \mathrm{L}$ theobromine has great potential to increase enamel remineralization process.

Theobromine, alkaloid extract from Cocoa Pod and APF gel has ability to enhance enamel remineralization. This research aimed to discover the differences between the enamel surface hardness of bovine teeth after theobromine, cacao-pod alkaloid extract and acidulated phosphate fluoride gel.

\section{MATERIALS DAN METHODS}

This was an in-vitro laboratory experimental research with pre and post-test control group design. The workflow of this research were consisted of (1) The making of Cocoapod theobromine extract at BPKI Ketintang Surabaya, (2) The making of enamel samples, (3) Sample treatment and hardness test of tooth enamel surface in Metallurgy Laboratory, ITS Faculty of Industrial Technology, Surabaya.

The theobromine concentration used was $200 \mathrm{mg} / \mathrm{L}$. The concentration of extract alkaloids obtained from cocoa pods was $1000 \mathrm{mg} / \mathrm{L}$. APF is a fluorine agent with a composition of $1.23 \%$ fluorine ions. The carbonated drink used in this research had acidic $\mathrm{pH}$.

Samples were using 28 bovine incisors; crown is separated from its roots. The crown is shaped into $1 \mathrm{x} 1 \mathrm{~cm}$ square, planted in a $2 \mathrm{~cm}$ diameter round resin mold and a width of $1.5 \mathrm{~cm}$. The sample separated into four groups; (1) The control group was immersed in carbonated drink for 75 minutes, (2) The Group I was immersed in carbonated drink for 75 minutes then then exposed to theobromine $200 \mathrm{mg} / \mathrm{L}$
0.1 gram for 5 minutes, (3) The Group II was immersed in carbonated drink for 75 minutes then exposed to cocoa-pod alkaloid extract $1000 \mathrm{mg} / \mathrm{L}$ for 5 minutes, (4) The Group III was immersed in carbonated drink for 75 minutes then exposed to APF gel for 5 minutes.

The measurement of enamel hardness was done pre and post treatment to discover the indentation power on labial surface of each sample with load of $200 \mathrm{~g}$ using Vickers Microhardness Tester in Vickers Hardness Number (VHN). The results were statistically analyzed using Shapiro-Wilk normality test, homogeneity test using Levene Test, OneWay ANOVA, and significance test using Tukey HSD.

\section{RESULTS}

In this research, the data were obtained in the form of enamel hardness on each indentation, then averaged and the standard deviation of each group was count. The enamel hardness measurement data were collected then divided into several groups, namely the control group (no treatment applied), the treatment group I (APF), group II (cocoa-pod alkaloid extract $100 \mathrm{mg} / \mathrm{L}$ ) and group III (Theobromine 200 $\mathrm{mg} / \mathrm{L})$. The average value is shown on Table 1.

The normality test was using The Shapiro-Wilk Test, the results from each group had value of $\mathrm{p}>0,05$ in conclusion, the data are normally distributed. Then the statistical analysis continued with One-Way ANOVA test and the results obtained $p=0,475(p>0,05)$, it can be concluded that there was no significant difference between enamel surface hardness on initial group. The homogeneity test was conducted using Levene's Test and obtained results of $\mathrm{p}=$ $0,085(p>0,05)$, therefore it can be stated that data variances between groups are homogeneous.

One-Way ANOVA test was conducted to discover the average differences among all groups of samples after remineralization. Analysis followed with Post-Hoc Multiple Comparison Test using the Tukey HSD method to discover whether there are any differences between the sample groups.

Table 1. Average value and standard deviation of enamel surface hardness post remineralization on each group

\begin{tabular}{lccccc}
\hline \multirow{2}{*}{ Groups } & \multirow{2}{*}{$\mathrm{n}$} & \multicolumn{3}{c}{ Average Value (VHN) } & \multirow{2}{*}{ Standard Deviation } \\
\cline { 3 - 5 } & & Initial Hardness & Post-Demineralization & Post-Remineralization & 8.44 \\
Control & 7 & 330.78 & 220.4 & 221.21 & 281.37 \\
I (Theobromine) & 7 & 329.46 & 217.56 & 270.66 & 19.82 \\
II (Alkaloid) & 7 & 324.69 & 224.1 & 244.29 & 8.21 \\
III (APF gel) & 7 & 331.36 & 218.96 & & \\
\hline
\end{tabular}

Table 2. The significant differences of enamel surface between group treatment post remineralization.

\begin{tabular}{|c|c|c|c|c|}
\hline Group & Control & Theobromine & Alkaloid & APF \\
\hline Control & & $\mathrm{P}=0.000^{*}$ & $\mathrm{P}=0.000^{*}$ & $\mathrm{P}=0.022 *$ \\
\hline Theobromine & $\mathrm{P}=0.000^{*}$ & & $\mathrm{P}=0.479$ & $\mathrm{P}=0.000^{*}$ \\
\hline Alkaloid & $\mathrm{P}=0.000^{*}$ & $\mathrm{P}=0.479$ & & $\mathrm{P}=0.008^{*}$ \\
\hline $\mathrm{APF}$ & $\mathrm{P}=0.022^{*}$ & $\mathrm{P}=0.000^{*}$ & $\mathrm{P}=0.008^{*}$ & \\
\hline
\end{tabular}


The test results showed a significant difference between control group and theobromine group, control group and alkaloid group, control group and APF gel group, theobromine group and APF gel group, and alkaloid group to APF gel group. In the other hand, there is no significant difference between theobromine group and alkaloid group.

\section{DISCUSSION}

The research results, all groups experienced enamel hardness reduction after immersion in carbonated drinks. In certain level of acidity, it can chemically dissolve the enamel mineral content, weakening teeth, increase sensitivity, and susceptible to damage leading to dental caries ${ }^{14,15}$. Demineralization prevention on the enamel surface is the key effort to avoid dental caries 9

In this research APF Group showed an increase in enamel surface hardness, this shows a lower value compared to theobromine group and alkaloid group but higher to the control group. APF gel has been used extensively in daily practice due to anticariogenic capabilities that have been proven in laboratory, clinical and epidemiological studies ${ }^{16}$. Corresponding to the latest research by Cury \& Delbem ${ }^{17}$ they proved a significant increase in enamel surface hardness after APF gel exposure compared to the control group, and there was no significant difference between the duration of exposure for 1 minute and 4 minutes. Maden et al. ${ }^{18}$ in his research stated that APF gel can reduce the minerals amount of minerals that are soluble in enamel that have been exposed to acidic drinks. The increase in enamel surface hardness is caused by the acidic properties of APF gel which has a $\mathrm{pH}$ among 3.6-3.9. The low $\mathrm{pH}$ in solution has a strong influence on the CaF2 formation, and also the low $\mathrm{pH}$ of the solution can slightly increase the enamel micro porosity and precipitate large amounts of $\mathrm{CaF}_{2}$ on the tooth surface ${ }^{4,16}$. Acidic $\mathrm{pH}$ of APF gel can help increase the compounding of fluoride into the enamel and negative fluoride ions become reactive in acidic media, thereby increasing the $\mathrm{CaF}_{2}$ formation. Formation of a $\mathrm{CaF}_{2}$ layer on tooth surface that acts as a fluoride reservoir when in acidic atmosphere, fluoride is released from $\mathrm{CaF}_{2}$ to form fluorapatite or fluor hydroxyapatite which makes minerals in enamel susceptible to dissolve. However, The formed fluorapatite can increase the tooth enamel hardness, although, the increase is not significant than theobromine group and alkaloid group ${ }^{2}$.

In this research, the alkaloid group showed an increase in enamel hardness, where it was lower than theobromine group but higher when compared to the APF group and control group. The dominant alkaloids in cocoa pod extracts are theobromine, caffeine and theophylline, which derive from xanthine ${ }^{9}$. In the methylxanthine compound there are many phenolic compounds which have a hydroxy group $\left(\mathrm{OH}^{-}\right)$. Phenolic provides a beneficial antioxidant effect, research has shown that phenolic compounds are the main source of natural antioxidants in plants. In addition to phenolic compounds, there are many methyl compounds and amine compounds which can also support the antioxidant effect of the cocoa fruit alkaloid extract. Antioxidants will play a role in increasing the value of the bond strength in enamels ${ }^{19}$. In the study of Nari-Ratih \& Widyastuti ${ }^{20}$ stated that free radicals have an important role in the onset and dental caries growth. Antioxidants can inhibit caries growth or delay the caries expansion. Thereby, the antioxidant content in alkaloids can increase the enamel surface hardness by increasing the enamel bond strength value.

The theobromine exposure in this research went through the apatite-forming-system and methylation of partially alkylated xanthine substituted to produce a product called theobromine apatite $\mathrm{Ca}_{10}\left(\mathrm{PO}_{4}\right)_{6}\left(\mathrm{OHC}_{7} \mathrm{H}_{8} \mathrm{~N}_{4} \mathrm{O}_{2}\right)$, with this formula, the apatite crystals produced with a size four times larger ${ }^{21}$. In the apatite crystal cell unit there is a micro tunnel with a diameter of $\pm 176 \mathrm{pm}$, making it possible for smaller ions to pass through the micro tunnel ${ }^{22}$. Some ions in theobromine have smaller diameters than micro tunnels, namely $\mathrm{C}=170 \mathrm{pm}, \mathrm{N}=152 \mathrm{pm}$, and $\mathrm{H}=152 \mathrm{pm}$. Other ion substitution in the apatite crystal will change the physical properties of the apatite. The compact arrangement of apatite crystals increases the attraction between the atoms ${ }^{22}$. Thus, it can be stated that the application of a larger crystal structure will become denser and increase the strength between the atoms. Therefore, an acid which has greater strength is needed to attract an ions from apatite crystals cause solubility and decrease in enamel hardness ${ }^{23}$.

Alkaloids and theobromine are alternative ingredients that can be used to replace fluoride, by providing a better remineralization effect and minimum side effects ${ }^{22}$. In research by Nakamoto, Falster $\&$ Simmons $^{24}$ stated that theobromine does not provide toxic effects to body, this statement supported with study by Kayaputri et al. ${ }^{25}$ which claimed that cacao seed coat extract is not potentially toxic. Cacao-pod alkaloid extract and theobromine can efficiently increase enamel surface hardness with affordable price ${ }^{9}$.

From this research it was found that every treatment group and control group had different values of enamel hardness measurement. Descriptively, theobromine group has the highest value, followed by the alkaloid, the APF and the control group. The data analysis results showed that there were significant differences between theobromine and alkaloid groups on the APF and control groups, this explained that the remineralization effect of the alkaloid and theobromine are better than the APF. But there is no difference between theobromine and alkaloid group, it showed that the remineralization effect of the given alkaloids and theobromine is comparable. This is in line with research conducted by Permatasari et al. ${ }^{9}$ stated that alkaloid with the concentration of $1000 \mathrm{mg} / \mathrm{L}$ which contain theobromine, caffeine and theophylline has the ability to increase enamel surface hardness value and did not differ significantly from single theobromine with $500 \mathrm{mg} / \mathrm{L}$ concentration. The enamel surface hardness of bovine incisors after exposure from theobromine, coco-pod alkaloid extract is harder than exposure to acidulated phosphate fluoride (APF). 


\section{REFERENCES}

1. Duraisamy Y, Chaly PE, Priyadarshni VI, Mohammed J, Vaishnavi. Evaluation of remineralization potential of theobromine on human enamel surfaces - An in vitro study. 2018;(February):435-8.

2. McCabe J, Walls A. Applied Dental Materials Ninth Edition. 9th ed. Blackwell Munksgaard; 2015.

3. Nugroho JJ, Hafsari WR. The effectiveness of betel leaf(Piper betle Linn) extract gel and cocoa bean (Theobroma cacao L) extract gel application against the hardness of enamel surface in vitro. J Dentomaxillofacial Sci. 2017;2(1):29.

4. Fejerskov O, Kidd E, editors. Dental Caries: The Disease and its Clinical Management. Blackwell Munksgaard; 2003. 368 p.

5. Robinson C, Brookes SJ, Kirkham J. Matrix : nature and function. Eur J Oral Sci. 1998;106:282-91.

6. Rao A, Malhotra N. The role of remineralizing agents in dentistry: A review. Compend contiuniung Educ i Dent. 2011;32(6):25-34.

7. Irmaleny I, Hidayat OT, Sulistianingsih S. The remineralization potential of cocoa (Theobroma cacao) bean extract to increase the enamel micro hardness (IN PRESS). Padjadjaran J Dent. 2017;29(2).

8. Cury JA, Tenuta LMA. Enamel remineralization : controlling the caries disease or treating early caries lesions ? § Dental caries : the disease and its signals Enamel remineralization. 2009;23:23-30.

9. Permatasari R, SuniartiDF, HerdaE, Mas'udZA. Identification of alkaloids of Indonesian Cacao beans (Theobroma cacao L.) and its effect on tooth enamel hardness. J Med Plants Res. 2016;10(15):202-8.

10. Avidhianita D, Damiyanti M, Irawan B, Noerdin A. Effect of Acidulated Phosphate Fluoride Gel Application on the Surface Roughness of Resin Sealant. J Phys Conf Ser. 2018 Aug;1073:032007.

11. Suryana M, Irawan B, Soufyan A. The Effects of Toothpastes Containing Theobromine and Hydroxyapatite on Enamel Microhardness after Immersion in Carbonated Drink. J Phys Conf Ser. 2018;1073(3)

12. Amaechi BT, Porteous N, Ramalingam K, Mensinkai PK, Ccahuana Vasquez RA, Sadeghpour A, et al. Remineralization of artificial enamel lesions by theobromine. Caries Res. 2013;47(5):399-405.

13. Sadeghpour A. A neural network analysis of theobromine vs. fluoride on the enamel surface of human teeth:
An experimental case study with strong implications for the production of a new line of revolutionary and natural non-fluoride based dentifrices. Diss Abstr Int. 2007;68(07):150.

14. Qasthari AI, Irawan B, Herda E. The influence of brushing with theobromine and sodium monofluorophosphate toothpaste on enamel surface resistance to roughness after demineralization. J Phys Conf Ser. 2018;1073(3).

15. Vanishree. N. Carbonated Drinks - Can of Poison. Ann Essences Dent. 2012;4(1):77-81.

16. Arief P E, Kunarti S. The effect of acidulated phosphate fluoride application on dental enamel surfaces hardness. Dent J (Majalah Kedokt Gigi). 2007;40(3):144.

17. Cury JA, Delbem ACB. Effect of application time of APF and $\mathrm{NaF}$ gels on microhardness and fluoride uptake of in vitro enamel caries. Am J Dent. 2002;15(3):169-72.

18. Maden EA, Acar Ö, Altun C, Polat GG. The Effect of Casein Phosphopeptide-Amorf Calcium Phosphate and Acidulated Phosphate Fluoride Gel on Dental Erosion in Primary Teeth: An in Vitro Study . J Clin Pediatr Dent. 2017;41(4):275-9.

19. Vieira MA, Maraschin M, Pagliosa CM, Podestá R, de Simas KN, Rockenbach II, et al. Phenolic acids and methylxanthines composition and antioxidant properties of mate (ilex paraguariensis) residue. J Food Sci. 2010;75(3): 280-5.

20. Nari-Ratih D, Widyastuti A. Effect of antioxidants on the shear bond strength of composite resin to enamel following extra-coronal bleaching. J Clin Exp Dent. 2019;11(2):e12632.

21. Nakamoto T, Simmons WB, Mineral M, Museum G. Apatiteforming-systems : methods and products ( 12 ) United States Patent. 2001;(February 2015).

22. Nasution AI, Zawil C. The comparison of enamel hardness between fluoride and theobromine application. Int J Contemp Dent Med Rev. 2015;(February):4.

23. Herisa HM, Noerdin A, Eriwati YK. The effect of theobromine $200 \mathrm{mg} / \mathrm{l}$ topical gel exposure duration against surface enamel hardness resistance from $1 \%$ citric acid. J Phys Conf Ser. 2017;884(1).

24. Nakamoto T, Falster AU, Simmons WB. Theobromine: A Safe and Effective Alternative for Fluoride in Dentifrices. J Caffeine Res. 2016;6(1):1-9.

25. Kayaputri IL, Sumanti DM, Djali M, Indiarto R, Dewi DL. Kajian Fitokimia Ekstrak Kulit Biji Kakao (Theobroma cacao L.). Chim Nat Acta. 2014;2(1):83-90. 